\title{
Four new combinations in Jacobaea Mill. (Asteraceae, Senecioneae) for the European flora
}

\author{
Gabriele Galasso $^{1 *}$, Fabrizio Bartolucci ${ }^{2}$
}

\begin{abstract}
Based on recent advances in the phylogeny of Senecioneae, several genera, including Jacobaea, are currently separated from traditional Senecio. New combinations are here proposed for four European taxa: J. disjuncta (Flatscher, Schneew. \& Schönsw.) Galasso \& Bartolucci, J. insubrica (Chenevard) Galasso \& Bartolucci, J. norica (Flatscher, Schneew. \& Schönsw.) Galasso \& Bartolucci and J. racemosa subsp. kirghisica (DC.) Galasso \& Bartolucci.
\end{abstract}

Key words: Jacobaea, nomenclature, Senecio.

Riassunto - Quattro nuove combinazioni in Jacobaea Mill. (Asteraceae, Senecioneae) per la flora europea.

Sulla base dei recenti progressi nella filogenesi delle Senecioneae, dal tradizionale genere Senecio vengono oggi separati più generi, tra i quali Jacobaea. Per quattro entità della flora europea vengono qui proposte le nuove combinazioni $J$. disjuncta (Flatscher, Schneew. \& Schönsw.) Galasso \& Bartolucci, J. insubrica (Chenevard) Galasso \& Bartolucci, J. norica (Flatscher, Schneew. \& Schönsw.) Galasso \& Bartolucci e J. racemosa subsp. kirghisica (DC.) Galasso \& Bartolucci.

Parole chiave: Jacobaea, nomenclatura, Senecio.

In recent years, the tribe Senecioneae (Asteraceae) has undergone a major sectional and generic reorganization, and several genera have been narrowly defined (Pelser et al., 2007; Nordenstam et al., 2009). Jacobaea Mill. is one of these resurrected and narrowly circumscribed genera and comprises ca. 45 species, most of them formerly classified within Senecio sect. Jacobaea (Mill.) Dumort. (i.e. Wiebe, 2000; Pelser et al., 2002, 2003, 2006; Nordenstam,

\footnotetext{
Sezione di Botanica, Museo di Storia Naturale di Milano, Corso Venezia 55, 20121 Milano, Italia

2 Scuola di Bioscienze e Medicina Veterinaria, Università di Camerino; Centro Ricerche Floristiche dell'Appennino, Parco Nazionale del Gran Sasso e Monti della Laga, San Colombo, 67021 Barisciano (AQ), Italia

E-mail: fabrizio.bartolucci@gmail.com

*Corresponding author: gabriele.galasso@comune.milano.it

(C) 2015 Gabriele Galasso, Fabrizio Bartolucci
}

Received: 11 June 2015

Accepted for publication: 14 July 2015
2006; Nordenstam \& Greuter, 2006; Peruzzi et al., 2006). Several Jacobaea taxa are karyologically heterogeneous, having two or more ploidy levels (cfr. Bolkhovskikh et al., 1969; Dobeš \& Vitek, 2000; Hodálová et al., 2010, 2015), among which there is Jacobaea carniolica (Willd.) Schrank complex (三Senecio carniolicus Willd. s.1.), with three ploidy levels discovered (Schönswetter et al., 2007; Suda et al., 2007; Hülber et al., 2009; Sonnleitner et al., 2010).

Three Alpine species belonging to the Jacobaea carniolica polyploid complex (one resurrected and two new to science: Flatscher et al., 2015) and one subspecies from Kazakhstan, Ukraine and Russia (Calvo et al., 2015) lack combination in Jacobaea. In order to provide correct names for these entities involved in the Italian flora (Conti et al., in prep.) and/or Euro+Med (Greuter, 2006 onwards) treatments, which accept this genus (Nordenstam \& Greuter, 2006; Peruzzi, 2007), new combinations are here established as follows.

Jacobaea disjuncta (Flatscher, Schneew. \& Schönsw.) Galasso \& Bartolucci, comb. nov. Bas.: Senecio disjunctus Flatscher, Schneew. \& Schönsw., Phytotaxa, 213 (1): 9 (-10, 20-21, figs. 1d, 3b, 4d, map). 2015 [11 Jun 2015, e-published].

Jacobaea insubrica (Chenevard) Galasso \& Bartolucci, comb. nov. Bas.: Senecio carniolicus Willd. var. insubricus Chenevard, Bull. Herb. Boissier, ser. 2, 6 (5): 368 (367-368). 1906 [30 Apr 1906]. (三 Jacobaea carniolica (Willd.) Schrank subsp. insubrica (Chenevard) Pelser $\equiv$ Jacobaea incana (L.) Veldkamp subsp. insubrica (Chenevard) B.Nord. \& Greuter $\equiv$ Senecio incanus L. subsp. insubricus (Chenevard) Braun-Blanq. 三 Senecio insubricus (Chenevard) Flatscher, Schneew. \& Schönsw.)

Jacobaea norica (Flatscher, Schneew. \& Schönsw.) Galasso \& Bartolucci, comb. nov. Bas.: Senecio noricus Flatscher, Schneew. \& Schönsw., Phytotaxa, 213 (1): 9 (-10, 19-20, figs. 1c, 2b, 4c, map). 2015 [11 Jun 2015, e-published].

Jacobaea racemosa (M.Bieb.) Pelser subsp. kirghisica (DC.) Galasso \& Bartolucci, comb. nov. Bas.: Senecio kirghisicus DC., Prodr. [A. P. de Candolle], 6: 362. 1838 [1837 publ. early Jan 1838]. (三 Cineraria glabrata Ledeb. [1829], non Sw. [1806], nom. illeg., non Senecio glabratus Hook. \& Arn. [1830] $\equiv$ Cineraria auriculata 
Ledeb. [1833], non Senecio auriculatus Burm.f. [1768], non Jacobaea auriculata Schrank [1820] $\equiv$ Jacobaea kirghisica (DC.) E.Wiebe $\equiv$ Senecio racemosus (M.Bieb.) DC. subsp. kirghisicus (DC.) J.Calvo)

\section{REFERENCES}

Bolkhovskikh Z. V., Grif V. G., Zakharyeva O. I. \& Matveva T. S., 1969 - Chromosome numbers of flowering plants. Nauka, Leningrad.

Calvo J., Álvarez I. \& Aedo C., 2015 - Systematics of Senecio section Crociseris (Compositae, Senecioneae). Phytotaxa, 211 (1): 1-105.

Conti F., Peruzzi L., Galasso G. \& Bartolucci F. (eds.), in prep. - An updated checklist of the Italian vascular flora.

Dobeš C. \& Vitek E., 2000 - Documented chromosome number checklist of Austrian vascular plants. Verlag des Naturhistorischen Museums Wien, Wien.

Flatscher P., Escobar García P., Hülber K., Sonnleitner M., Winkler M., Saukel J., Schneeweiss G. M. \& Schönswetter P., 2015 - Understimated diversity in one of the world's best studied mountain ranges: The polyploid complex of Senecio carniolicus (Asteraceae) contains four species in the European Alps. Phytotaxa, 213 (1): 1-21.

Greuter W., 2006 onwards - Compositae (pro parte majore). In: Compositae. Euro+Med Plantbase - the information resource for Euro-Mediterranean plant diversity. Greuter W. \& Raab-Straube E. von (eds.). Available from: <http://ww2.bgbm.org/EuroPlusMed $>$ (retrieved on 7 May 2015).

Hodálová I., Mered'a P. Jr., Vinikárová A., Grulich V. \& Rotreklová O., 2010 - A new cytotype of Jacobaea vulgaris (Asteraceae): frequency, morphology and origin. Nordic Journal of Botany, 28 (4): 413-427.

Hodálová I., Mered'a P. Jr., Kučera J., Marhold K., Kempa M., Olšavská \& Slovák M., 2015 - Origin and systematic position of Jacobaea vulgaris (Asteraceae) octoploids: genetic and morphological evidence. Plant Systematics and Evolution, 301 (5): 1517-1541.

Hülber K., Sonnleitner M., Flatscher R., Berger A., Dobrovsky R., Niessner S., Nigl T., Schneeweiss G. M., Kubešová M., Rauchová J., Suda J. \& Schönswetter P, 2009 - Ecological segregation drives fine-scale cytotype distribution of Senecio carniolicus in the Eastern Alps. Preslia, 81 (3): 309-319.

Nordenstam B., 2006 - Additions to the genus Jacobaea Mill. (Compositae-Senecioneae). Compositae Newsletter, 44: 12-13.

Nordenstam B. \& Greuter W., 2006 - Jacobaea Mill. In: Euro-Med Notulae, 2 [Notulae ad floram euromediterraneam pertinentes No. 22]. Greuter W. \& Raab-Straube E. von (eds.). Willdenowia, 36 (2): 711-713.

Nordenstam B., Pelser P. B., Kadereit J. W. \& Watson L. E., 2009 - Senecioneae. In: Systematics, Evolution, and Biogeography of Compositae. Funk V. A., Susanna A., Stuessy T. F. \& Bayer R. J. (eds.). IAPT, Vienna: 503-525.
Pelser P. B., Gravendeel B. \& Meijden R. van der, 2002 Tackling speciose genera: species composition and phylogenetic position of Senecio sect. Jacobaea (Asteraceae) based on plastid and nrDNA sequences. American Journal of Botany, 89 (6): 929-939.

Pelser P. B., Gravendeel B. \& Meijden R. van der, 2003 Phylogeny reconstruction in the gap between too litlle and too much divergence: the closest relatives of Senecio jacobaea (Asteraceae) according to DNA sequences and AFLPs. Molecular Phylogenetics and Evolution, 29 (3): 613-628.

Pelser P. B., Veldkamp J.-F. \& Meijden R. van der, 2006 New combinations in Jacobaea Mill. (Asteraceae Senecioneae). Compositae Newsletter, 44: 1-11.

Pelser P. B., Nordenstam B., Kadereit J. W. \& Watson L. E., 2007 - An ITS phylogeny of tribe Senecioneae (Asteraceae) and a new delimitation of Senecio L. Taxon, 56 (4):1077-1104.

Peruzzi L., 2007 - Notula: 1310. In: Notulae alla checklist della flora vascolare italiana 3 (1267-1310). Conti F., Nepi C. \& Scoppola A. (eds.). Informatore Botanico Italiano, 39 (1): 252-253.

Peruzzi L., Passalacqua N. G. \& Jarvis C. E., 2006 - Typification of the accepted names in the Jacobaea maritima group (Asteraceae). Taxon, 55 (4): 1001-1004.

Schönswetter P., Lachmayer M., Lettner C., Prehsler D., Rechnitzer S., Reich D. S., Sonnleitner M., Wagner I., Hülber K., Schneeweiss G. M., Trávníček P. \& Suda J., 2007 - Sympatric diploid and hexaploid cytotypes of Senecio carniolicus (Asteraceae) in the Eastern Alps are separated along an altitudinal gradient. Journal of Plant Research, 120 (6): 721-725.

Sonnleitner M., Flatscher R., García P. E., Rauchová J., Suda J., Schneeweiss G. M., Hülber K. \& Schönswetter P., 2010 - Distribution and habitat segregation on different spatial scales among diploid, tetraploid and hexaploid cytotypes of Senecio carniolicus (Asteraceae) in the Eastern Alps. Annals of Botany, 106 (6):967977.

Suda J., Weiss-Schneeweiss H., Tribsch A., Schneeweiss G. M., Trávníček P. \& Schönswetter P., 2007 - Complex distribution patterns of di-, tetra-, and exaploid cytotypes in the European high mountain plant Senecio carniolicus (Asteraceae). American Journal of Botany, 94 (8): 1391-1401.

Wiebe E. I., 2000 - The annotated check-list of the tribe Senecioneae Cass. (Asteraceae) in Siberia. Turczaninowia, 3 (4): 58-63. 